\title{
EVALUASI DAYA TARIK WISATA LANSKAP SEJARAH ISTANA ALWATZIKHOEBILLAH SAMBAS KALIMANTAN BARAT
}

\author{
Sabahan Mawazi \\ Program Studi Manajemen Bisnis Pariwisata, Politeknik Negeri Sambas \\ email: sabahan_polteksbs@yahoo.com
}

\begin{abstract}
The Alwadzikhoebillah Palace area is a cultural heritage related to the history of ancient Sambas. The landscape of the palace building is in the form of a stage and is located close to the river. Rivers are the main infrastructure in carrying out social and government activities. In addition to government interests, the existence of the Alwadzikhoebillah Palace area near the river is also based on the philosophy of the Malay community who believes that a good building location is a place close to a spring. This study uses quantitative and descriptive methods to analyze the relationship between existing data by looking at the potential and constraints that affect tourism activities. The quantitative method was carried out using a simple scoring technique based on the criteria of MacKinnon et al. (1986) with several modifications adapted to the conditions and research needs to assess the potential as a tourist attraction which consists of several components. This evaluation indicates that the Alwatzikhoebillah Palace area actually has two tourist objects and attractions (67\%) in the very potential category (S1) and one tourist object and attraction (33\%) in the quite potential category (S2). Objects and tourist attractions in the Alwadzikhoebillah Palace area have good access values. All of these accesses are in good condition, namely in the form of flat asphalt roads with no holes and can be passed by two and four-wheeled vehicles. It's just that in the dining area the ease of access is worth less due to the limited parking area for visitors.
\end{abstract}

Keywords: Evaluation, Historical Landscape, and The Alwadzikhoebillah Palace

\section{PENDAHULUAN}

Lanskap merupakan bentang alam yang mempunyai karakteristik tertentu yang dapat dinikmati oleh seluruh indra manusia. Lanskap sejarah merupakan suatu model atau bentuk yang dimiliki dari lanskap binaan, yang dibentuk oleh suatu nilai sejarah yang dimiliki suatu kelompok masyarakat yang dikaitkan dengan sumber daya alam dan lingkungan yang ada pada tempat tersebut. Lanskap tipe ini merupakan hasil interaksi antara manusia dan alam lingkungannya yang merefleksikan adaptasi manusia dan juga perasaan serta ekspresinya dalam menggunakan dan mengelola sumber daya alam dan lingkungan terkait erat dengan lingkungannya. Lanskap sejarah merefleksikan interaksi antara manusia dan lingkungan alaminya dalam ruang dan waktu. Alam dalam konteks ini adalah padanan dari kelompok manusia, keduanya merupakan kekuatan dinamis yang membentuk lanskap sejarah. Wisata sejarah merupakan suatu kegiatan wisata di kawasan bersejarah terutama menelusuri benda-benda hasil karya manusia masa lalu, baik benda yang bergerak maupun yang tidak bergerak. Objek peninggalan sejarah tidak hanya terbatas pada bentuk fisik tetapi juga termasuk di dalamnya aspek sosial masyarakat yang bersangkutan.

Masyarakat di kabupaten Sambas pada umumnya sangat menyadari akan potensi 
wisata sejarah di kawasan istana Alwatzikhoebillah. Keberadaan istana yang berada di tepian simpang tiga sungai Sambas, benda pusaka kerajaraan yang tersimpan di dalam istana, keberadaan makam para sultan, dan masjid Jami istana dengan berbagai keunikan di dalamnya mengindikasikan akan besarnya potensi pengembangan sektor wisata di wilayah tersebut. Namun, di tengah berbagai potensi wisata yang dimiliki, sektor wisata sejarah masih belum berkembang sehingga tidak memberikan dampak signifikan terhadap pelestarian sejarah dan kesejahteraan masyarakat di wilayah ini. Oleh sebab itu penelitian ini diperlukan untuk menjawab pertanyaan bagaimana potensi lanskap bersejarah kawasan istana

Alwatzikhoebillah untuk pengembangan wisata sejarah. Penelitian ini bertujuan untuk mengevaluasi daya tarik wisata lanskap bersejarah kawasan istana Alwatzikhoebillah sebagai upaya pengembangan wisata sejarah di kabupaten Sambas.

\section{METODE PENELITIAN}

\section{Waktu dan Tempat Penelitian}

Waktu pelaksanaan penelitian ini dari mulai persiapan kegiatan hingga pelaporan dilaksanakan selama 6 bulan terhitung dari bulan Pebruari sampai dengan bulan Juli 2020, sedangkan tempat penelitian ini berlokasi di kawasan istana Alwadzikhoebillah Kabupaten Sambas Kalimantan Barat.

\section{Pendekatan Penelitian Studi Pustaka}

Metode ini dilakukan sebagai langkah awal untuk mengetahui kondisi umum lokasi penelitian serta membantu pengumpulan informasi-informasi umum terdahulu yang berkaitan dengan masalah penelitian. Studi pustaka dilakukan dengan cara mengumpulkan, mempelajari, dan menelaah buku-buku, majalah-majalah, brosur-brosur, dokumen-dokumen, yang berkaitan dengan tujuan penelitian. Data yang diperlukan untuk penunjang penelitian sesuai dengan batasan dan perumusan masalah didapatkan berupa hardcopy dan softcopy melalui instansi pemerintah daerah, internet, pustaka buku, dan lainlain.

\section{Wawancara}

Wawancara atau interview merupakan proses interaksi dan komunikasi antara pengumpul data dan responden. Kegiatan wawancara secara langsung menggunakan panduan wawancara dengan berbagai pihak yaitu instansi terkait, pengelola, dan masyarakat. Sedangkan penyebaran kuisioner kepada responden dilakukan secara purposive sampling, dalam hal ini yang menjadi responden adalah masyarakat di lokasi penelitian.

\section{Survei Lapangan}

Metode ini dilakukan untuk mengumpulkan data dengan cara mengamati, meneliti, dan mengukur kejadian yang sedang berlangsung, sehingga diperoleh data yang faktual dan aktual. Pengamatan lapangan dilakukan untuk menggali potensi sumber daya yang memungkinkan untuk dikembangkan sebagai objek/atraksi wisata. Pengamatan lapangan juga dilakukan untuk memperoleh posisi dari masing-masing objek/atraksi, jalur sirkulasi, fasilitas wisata sejarah.

\section{Analisis}

Tahap analisis dilakukan dengan menggunakan metode kuantitatif dan deskriptif untuk menganalisis keterkaitan data yang ada dengan melihat potensi dan kendala yang mempengaruhi kegiatan wisata. Metode kuantitatif dilakukan dengan menggunakan teknik skoring sederhana berdasarkan kriteria Mc Kinnon et al. (1986) dengan beberapa modifikasi yang disesuaikan dengan kondisi dan kebutuhan penelitian untuk menilai 
potensi sebagai objek wisata yang terdiri dari beberapa komponen.

\section{Teknik Evaluasi}

Pengembangan kawasan wisata di suatu kawasan dimulai dengan menentukan objek dan atraksi wisata yang tersedia dan selanjutnya dinilai potensinya. Dalam penelitian ini, penilaian potensi kawasan wisata dilakukan dengan menggunakan metode modifikasi Mc Kinnon (1986) dan Gunn (1994) dengan responden ahli $(n=8)$ sebagai penilai. Pemilihan responden ahli didasari oleh asumsi bahwa responden tersebut merupakan orang yang mengetahui sejarah dan ilmu pengetahuan di bidang wisata serta dapat mewakili masyarakat di sekitar kawasan istana tersebut. Penilaian objek wisata dilakukan dengan memenuhi aspek berikut, yaitu aspek keberadaan (letak dari jalan utama estetika dan keaslian, transportasi dan aksessibilitas, atraksi dan keunikan, fasilitas pendukung, ketersediaan air bersih, dan dukungan masyarakat. Penilaian terhadap objek dan atraksi wisata sesuai dengan standar modifikasi Mc Kinnon (1986) dan Gunn (1994) dapat dilihat pada Tabel 1 .

Tabel 1. Penilaian Terhadap Objek dan Atraksi Wisata

\begin{tabular}{|c|c|c|c|c|c|c|}
\hline \multirow[b]{2}{*}{ No. } & \multirow{2}{*}{\multicolumn{2}{|c|}{ Faktor }} & \multicolumn{4}{|c|}{ Nilai } \\
\hline & & & $\begin{array}{c}4 \\
\text { (Sangat } \\
\text { Kuat) }\end{array}$ & $\begin{array}{c}3 \\
\text { (Kuat) }\end{array}$ & $\begin{array}{c}2 \\
\text { (Sedang) }\end{array}$ & $\begin{array}{c}1 \\
\text { (Lemah) }\end{array}$ \\
\hline 1 & $\begin{array}{l}\text { Letak dari } \\
\text { utama }\end{array}$ & jalan & $<1 \mathrm{~km}$ & $1-2 \mathrm{~km}$ & $2-3 \mathrm{~km}$ & $>3 \mathrm{~km}$ \\
\hline 2 & $\begin{array}{l}\text { Estetika dan } \\
\text { keaslian }\end{array}$ & & $\begin{array}{l}\text { Keindahan } \\
\text { alam yang } \\
\text { masih asli }\end{array}$ & $\begin{array}{l}\text { Asimilasi, } \\
\text { dominan } \\
\text { bentuk asli }\end{array}$ & $\begin{array}{l}\text { Asimilasi, } \\
\text { dominan } \\
\text { bentuk baru }\end{array}$ & $\begin{array}{l}\text { Sudah } \\
\text { berubah } \\
\text { sama sekali }\end{array}$ \\
\hline 3 & $\begin{array}{l}\text { Atraksi dan } \\
\text { keunikan }\end{array}$ & & $\begin{array}{l}\text { Hanya } \\
\text { terdapat di } \\
\text { tapak }\end{array}$ & $\begin{array}{l}\text { Terdapat }<3 \\
\text { lokasi } \\
\text { ditempat lain }\end{array}$ & $\begin{array}{l}\text { Terdapat } 3-5 \\
\text { di tempat } \\
\text { lain }\end{array}$ & $\begin{array}{l}\text { Terdapat > } \\
5 \text { lokasi di } \\
\text { tempat lain }\end{array}$ \\
\hline 4 & $\begin{array}{l}\text { Fasilitas } \\
\text { pendukung }\end{array}$ & & $\begin{array}{l}\text { Tersedia } \\
\text { dalam } \\
\text { kondisi } \\
\text { sangat baik }\end{array}$ & $\begin{array}{l}\text { Tersedia } \\
\text { dalam } \\
\text { kondisi baik }\end{array}$ & $\begin{array}{l}\text { Tersedia } \\
\text { dalam } \\
\text { kondisi } \\
\text { kurang baik }\end{array}$ & $\begin{array}{l}\text { Prasarana } \\
\text { dan sarana } \\
\text { tidak } \\
\text { tersedia }\end{array}$ \\
\hline 5 & $\begin{array}{l}\text { Ketersediaan } \\
\text { bersih }\end{array}$ & air & $<0,5 \mathrm{~km}$ & $0,5-1 \mathrm{~km}$ & $1-2 \mathrm{~km}$ & $\begin{array}{l}\text { Jarak }>2 \\
\mathrm{~km}\end{array}$ \\
\hline 6 & $\begin{array}{l}\text { Transportasi } \\
\text { aksesibilitas }\end{array}$ & dan & $\begin{array}{l}\text { Jalan aspal, } \\
\text { ada } \\
\text { kendaraan } \\
\text { umum }\end{array}$ & $\begin{array}{l}\text { Jalan aspal } \\
\text { berbatu, ada } \\
\text { kendaraan } \\
\text { umum }\end{array}$ & $\begin{array}{l}\text { Jalan aspal } \\
\text { berbatu } \\
\text { tanpa } \\
\text { kendaraan } \\
\text { umum }\end{array}$ & $\begin{array}{l}\text { Jalan } \\
\text { berbatu/ } \\
\text { tanah tanpa } \\
\text { kendaraan } \\
\text { umum }\end{array}$ \\
\hline 7 & $\begin{array}{l}\text { Dukungan } \\
\text { Masyarakat }\end{array}$ & & $\begin{array}{l}\text { Sangat } \\
\text { mendukung }\end{array}$ & Mendukung & $\begin{array}{l}\text { Kurang } \\
\text { mendukung }\end{array}$ & $\begin{array}{l}\text { Tidak } \\
\text { mendukung }\end{array}$ \\
\hline
\end{tabular}

Sumber : Modifikasi Mc Kinnon (1986) dan Gunn (1994) 
Penghitungan penilaian terhadap objek dan atraksi wisata:

$$
\sum_{n=1}^{8} \mathrm{Flju}+\sum_{n=1}^{8} \mathrm{Fek}+\sum_{n=1}^{8} \mathrm{Fatk}+\sum_{n=1}^{8} \mathrm{Ffp}+\sum_{n=1}^{8} \mathrm{Fka}+\sum_{n=1}^{8} \mathrm{Fta}+\sum_{n=1}^{8} \mathrm{Fdm}
$$

Keterangan:

Flju = Faktor letak dari jalan utama

Fek $=$ Faktor estetika dan keaslian

Fatk = Faktor atraksi dan keunikan

Ffp $\quad=$ Faktor fasilitas pendukung

Fka $=$ Faktor ketersediaan air bersih

Fta $=$ Faktor transportasi dan aksesibilitas

$\mathrm{Fdm}=$ Faktor dukungan masyarakat

$\sum_{n=1}^{8}=$ nilai responden ke 1 sampai 8

Skor hasil penjumlahan faktor di atas kemudian ditilai sesuai dengan kategori kelas masing-masing, di mana:

S1 = Sangat potensial mempunyai nilai 193 $-256$

S2 = Cukup Potensial mempunyai nilai 129 $-192$

S3 = Kurang potensial mempunyai nilai 65 $-128$

$\mathrm{N}=$ Tidak potensial mempunyai nilai $\leq 64$

\section{HASIL}

Kawasan Istana Alwatzikhoebillah memiliki tiga (3) titik wisata yang potensial untuk dikembangkan menjadi objek dan atraksi wisata sejarah. Penilaian kesesuaian objek dan atraksi wisata dilakukan untuk mengetahui sejauh mana potensi pengembangan kawasan wisata sejarah di kawasan Istana Alwatzikhoebillah. Secara umum, hasil dari analisis kelayakan objek dan atraksi wisata sejarah di kawasan Istana Alwatzikhoebillah menunjukkan bahwa objek dan atraksi wisata tersebut mempunyai potensi untuk dikembangkan. Upaya Pemerintah kabupaten Sambas dalam rangka promosi wisata sejarah Kawasan Istana Alwadzikhobillah salah satunya dengan cara mengadakan acara tahunan Ulang Tahun Kabupaten Sambas yang fokus kegiatannya berada di kawasan Istana Alwadzikhoebillah.

\section{PEMBAHASAN}

Berdasarkan hasil penilaian yang telah dilakukan, bahwa kawasan Istana Alwatzikhoebillah secara aktual memiliki 2 (67\%) objek dan atraksi wisata dengan kategori sangat potensial (S1) dan 1 (33\%) objek dan atraksi wisata dengan kategori cukup potensial (S2). Penilaian kelayakan objek dan atraksi wisata di kawasan Istana Alwatzikhoebillah disajikan dalam tabel 2.

Kawasan Istana Alwatzikhoebillah merupakan wilayah tepian sungai yang sangat luas, sehingga objek dan atraksi wisata di kawasan Istana Alwatzikhoebillah dapat mewakili berbagai karakteristik berdasarkan lingkungan (akuatik dan teresterial), dan sumber daya (sumber daya alam dan sumber daya budaya). Sungai yang terdapat di depan Istana Alwatzikhoebillah juga memiliki beragam karakteristik yang alami, yaitu simpang tiga sungai (pertemuan sungai Sambas Kecil, Subah dan Teberau), tampak dari kejauhan terdapat jembatan batu, rumah apung dan pasar Sambas. Demikian pula halnya dengan aktivitas perairan dapat ditemukan kegiatan masyarakat memancing, bersampan, dan lalu lintas motor air.

Berdasarkan ketersediaan objek/atraksi wisata sejarah, lokasi penelitian merupakan kawasan yang termasuk klasifikasi zona cukup atraktif dimana terdapat tiga objek/atraksi dalam satu kawasan wisata. 
Tabel 2. Penilaian Kelayakan Objek dan Atraksi Wisata Sejarah di Kawasan Istana Alwatzikhoebillah

\begin{tabular}{|c|c|c|c|c|c|c|c|c|c|c|}
\hline \multirow[b]{2}{*}{ No. } & \multirow[b]{2}{*}{ Objek/Atraksi Wisata } & \multicolumn{7}{|c|}{ Parameter } & \multirow[b]{2}{*}{ ᄒ̀ } & \multirow[b]{2}{*}{ 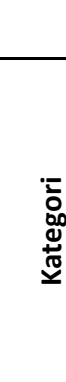 } \\
\hline & & 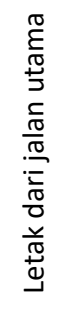 & 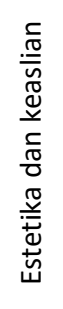 & 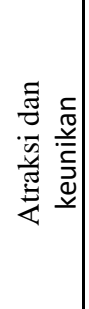 & 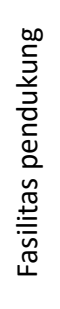 & 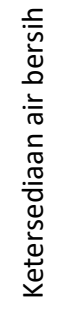 & 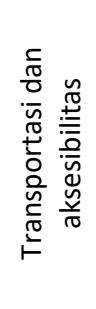 & 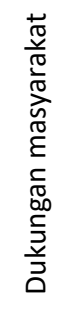 & & \\
\hline 1 & Bangunan Utama Istana & 32 & 25 & 30 & 24 & 24 & 32 & 32 & 199 & S1 \\
\hline 2 & Masjid Jami' & 32 & 19 & 24 & 21 & 30 & 28 & 32 & 176 & S2 \\
\hline 3 & Makam Kesultanan & 32 & 28 & 31 & 20 & 18 & 32 & 32 & 193 & S1 \\
\hline
\end{tabular}

Keterangan : Nilai penjumlahan skoring tiap responden penilai $(\mathrm{n}=8)$

S1= Sangat Potensial (nilai $193-256$ )

S2 = Cukup Potensial (nilai $129-192$ )

S3 = Kurang Potensial (nilai $65-128$ )

$\mathrm{N}=$ Tidak Potensial (nilai $\leq 64)$

Lanskap Kawasan Istana Alwadzikhoebillah secara keseluruhan dengan keberadaan sungai-sungai, bangunan-bangunannya, serta aktivitas/budaya masyarakat di sekitarnya menjadi daya tarik tersendiri. Dengan adanya daya tarik wisata yang tinggi dari suatu objek wisata akan membuatnya dikunjungi oleh banyak wisatawan. Daya tarik ini dapat berupa keunikan, estetika/ arsitektur, keutuhan, keaslian, dan kondisi fisik. Berbagai kajian yang dilakukan dalam penelitian ini diantaranya berkaitan dengan interpretasi dan kajian aksessibilitas (sirkulasi).

Interpretasi adalah suatu kegiatan memahami dan merasakan penampilan, nuansa, ataupun pesan yang disajikan dari suatu objek dan lingkungannya. Fasilitas interpretasi dan informasi sangat penting dalam kegiatan wisata sejarah untuk membantu para wisatawan memahami, merasakan, dan mendapatkan pengalaman dari objek yang dikunjunginya. Fasilitas interpretasi bermacam-macam seperti guide, leaflet, brosur, papan informasi, booklet, foto/gambar, museum, dan media elektronik. Keseluruhan objek dan lanskap sejarah di Kawasan Istana Alwadzikhoebillahini tidak mempunyai fasilitas interpretasi berupa guide, leaflet, booklet, foto/gambar, media elektronik, maupun papan informasi yang dapat memberikan penjelasan dan informasi kepada para pengunjung mengenai hal-hal yang berkaitan dengan objek-objek sejarah yang bersangkutan. Hal ini disebabkan karena lanskap bersejarah di kawasan Istana Alwadzikhoebillah ini belum dikelola secara khusus sebagai objek wisata sehingga belum memiliki fasilitas interpretasi.

Informasi mengenai objek dapat diperoleh para pengunjung apabila melakukan wawancara atau bertanya kepada pihak pengelola maupun pemiliknya langsung. Selain itu penjelasan dan informasi mengenai objek juga dapat diperoleh para pengunjung ketika mereka mengikuti kegiatan wisata yang diadakan oleh komunitas-komunitas pecinta sejarah maupun oleh instansi pemerintah pada waktu-waktu tertentu, misalnya dalam rangka peringatan hari 
bersejarah pemindahan Ibu Kota Kabupaten Sambas. Ketika mengikuti kegiatan ini para pengunjung secara khusus memperoleh informasi melalui guide dan booklet, sedangkan objek-objek yang dikunjungi tidak menyediakan media interpretasi sama sekali.

Kawasan Istana Alwadzikhoebillah ini belum terdapat Pusat Informasi Turis (Tourist Information Centre). Papan informasi maupun signboard yang menyatakan bahwa kawasan ini memiliki nilai historis yang tinggi juga belum ada. Tidak adanya fasilitas informasi baik di kawasan maupun objek-objek sejarah merupakan sebuah kendala dalam kegiatan wisata karena akan menyebabkan para pengunjung tidak dapat menangkap keseluruhan makna sejarah yang ada di dalamnya.

\section{Aksesibilitas dan Sirkulasi}

Untuk mendukung kemudahan dalam melakukan kegiatan wisata faktor aksesibilitas merupakan salah satu faktor yang harus diperhatikan. Faktor aksesibilitas yang dilihat di sini meliputi kondisi fisik, kemudahan, kapasitas, dan kejelasannya. Kondisi fisik adalah kondisi jalan dilihat dari segi fisiknya, apakah cukup layak sebagai akses keluar masuk objek sejarah, apakah jalan tersebut dalam kondisi baik atau buruk (rusak) sehingga perlu diperbaiki. Yang dimaksud dengan kemudahan di sini adalah kemudahan dalam menuju dan menggunakan akses keluar masuk tersebut, apakah terdapat rintangan dan kesulitan-kesulitan seperti jalan yang berliku, jalan yang menanjak, kemacetan, dan sebagainya. Kapasitas adalah kapasitas keluar masuk objek, apakah cukup digunakan untuk pengunjung dalam jumlah besar atau hanya dalam jumlah kecil saja. Sedangkan yang dimaksud dengan kejelasan adalah apakah keberadaan akses keluar masuk objek cukup jelas atau malah tersembunyi. Kejelasan disini dapat ditunjukkan dengan adanya papan penunjuk atau keteranganketerangan lainnya.

Berdasarkan hasil pengamatan lapangan, bahwa semua objek dan daya tarik yang ada pada kawasan Istana Alwadzikhoebillah ini memiliki nilai akses yang baik. Semua akses ini dalam kondisi baik yaitu berupa jalan aspal yang rata dan tidak berlubang serta dapat dilewati oleh kendaraan beroda dua dan empat. Hanya saja pada kawasan makan kemudahan akses bernilai kurang dikarenakan terbatasnya area parkir pengunjung sehingga sering terjadi kemacetan di ruas jalan mengingat kawasan ini merupakan jalur utama lalu lintas masyarakat. Posisi akses masingmasing objek cukup jelas dengan adanya papan nama jalan disetiap ruas jalan sehingga pengunjung dapat dengan mudah menemukan akses keluar masuk ini dari jalan raya.

\section{SIMPULAN}

1. Berdasarkan hasil penilaian yang telah dilakukan, bahwa kawasan Istana Alwatzikhoebillah secara aktual memiliki 2 objek dan atraksi wisata dengan kategori sangat potensial (S1) dan 1 objek dan atraksi wisata dengan kategori cukup potensial (S2).

2. Objek dan daya tarik wisata yang ada pada kawasan Istana Alwadzikhoebillah ini memiliki nilai akses yang baik. Semua akses ini dalam kondisi baik yaitu berupa jalan aspal yang rata dan tidak berlubang serta dapat dilewati oleh kendaraan beroda dua dan empat. Hanya saja pada kawasan makan kemudahan akses bernilai kurang dikarenakan terbatasnya area parkir pengunjung.

Hasil penelitian ini diharapkan dapat dijadikan referensi untuk Pemerintah Daerah khususnya Dinas Pariwisata, Pemuda, dan Olahraga kabupaten Sambas 
dalam pengembangan kawasan wisata sejarah istana Alwadzikhoebillah Sambas. Dalam pengembangannya, daya tarik wisata istana Alwadzikhoebillah perlu dilakukan pengelolaan yang kompehensif dan berkelanjutan.

\section{REFERENSI}

Agustus 2015. Hal 48-60 Oktadiyani, dkk. 2105. Strategi pengembangan wisata alam taman wisata alam Wera. Jurnal Wasian. Vol. 2. No 1. Tahun 2015. Hal. 9-20

BPS, 2019, Kabupaten Sambas Dalam Angka 2019. Kabupaten Sambas: Badan Pusat Statistik Kabupaten Sambas.

Fahmi, R. U, 2003. Selayang Pandang Kerajaan Islam Sambas. Majelis Adat Istiadat Kesultanan Sambas, Sambas.

Nazir. M, 2003. Metode Penelitian, Jakarta: Ghalia Indonesia.

Nurisjah, S. dan Q. Pramukanto. 2001. Perencanaan Kawasan Untuk Pelestarian Lanskap dan Taman Sejarah. Program Studi Arsitektur Pertamanan, Jurusan Budi Daya Pertanian, Fakultas Pertanian, IPB (tidak dipublikasikan). Bogor.

Rasodjo Tunggul. 2017. Pengembangan Pariwisata budaya dalam perspektif pelayanan Publik. Jurnal Office. Vol. 3. No. 1. Tahun 2017.

Sugiyono. 2015. Metode Penelitian Kuantitatif, Kualitatif, dan $R$ dan $D$. Bandung: Alfabeta

Sunaryo, Bambang. 2013. Kebijakan pembangunan Destinasi pariwisata. Yogyakarta: Gava Media

Undang-Undang Republik Indonesia (UU. RI) No. 10. 2009. Tentang Kepariwisataan. Jakarta: Depdagri; 2009
Wilopo dan Hakim. 2017. Strategi pengembangan destinasi pariwisata budaya. (Studi kasus pada kawasan situs trowulan sebagai pariwisata budaya unggulan di Kabupaten Mojokerto). Jurnal Administrasi Bisnis. Vol. 41. No 1. Januari 2017 Yahya. 2015. Potensi Pantai Tete sebagai daya tarik wisata di Kabupaten Bone. Jurnal Kepariwisataan. Vol. 09. No. 02 